\title{
Heavy Metal Accumulation in Selected Vegetables Irrigated with Untreated Sewage Waste Water in Allahabad City
}

\author{
Ghulam Rasoul Fazli ${ }^{1}$, Sangeeta Shukla ${ }^{2}$ \\ ${ }^{1}$ Ph.D Scholar, Warner School of Food and Dairy Technology ,SHIATS, Allahabad-211007, (U.P.) India \\ ${ }^{2}$ Assistant Professor, Warner School of Food and Dairy Technology ,SHIATS, Allahabad-211007, (U.P.) India
}

\begin{abstract}
The present study was conducted to assess the heavy metals ( $\mathrm{Cu}, \mathrm{Cd}, \mathrm{Pb}, \mathrm{Ni}$ ) concentration of vegetables ( Spinach, Cucumber, Ladyfinger, Ridge guard) irrigated with waste water in around yamna river of Allahabad district. Lead was several fold higher in all vegetables irrigated with waste water in both sites (Mahewa Path and Arail Ghat), the study showed that the concentration of lead varied greatly in all vegetables (Table 1,2). Spinach was having the higher average mean concentration of lead (18.764 mg/L), followed by Ladyfinger $(15.227 \mathrm{mg} / \mathrm{L})$, Ridge gourd $(5.117 \mathrm{mg} / \mathrm{L})$ and Cucumber $(2.602 \mathrm{mg} / \mathrm{L})$ and $\mathrm{Cu}(1.372 \mathrm{mg} / \mathrm{L})$ was higher in spinach followed by cucumber $(0.369 \mathrm{mg} / \mathrm{L})$, Ladyfinger $(0.182 \mathrm{mg} / \mathrm{L})$ and Ridge gourd $(0.170 \mathrm{mg} / \mathrm{L})$, in site one (Mahewa path). The average mean concentration of $P b$ in Spinach, Cucumber, Ladyfinger and Ridge gourd were $(4.333 \mathrm{mg} / \mathrm{L}),(5.079 \mathrm{mg} / \mathrm{L}),(10.407 \mathrm{mg} / \mathrm{L})$ and $(10.779 \mathrm{mg} / \mathrm{L})$ respectively, in case of Cu Ridge gourd $(0.269 \mathrm{mg} / \mathrm{L})$ got the highest amount followed by Spinach $(0.237 \mathrm{mg} / \mathrm{L})$, Cucumber $(0.227 \mathrm{mg} / \mathrm{L})$ and Ladyfinger $(0.218 \mathrm{mg} / \mathrm{L})$ in Arail Ghat. The study suggests that wastewater irrigation led to accumulation of heavy metals in food stuff causing potential health risk to consumers.
\end{abstract}

Keywords: Heavy metals, waste water, vegetables.

\section{Introduction}

The growing problem of water scarcity has significant negative influence on economic development, human livelihoods, and environmental quality throughout the world. Rapid urbanization and industrialization releases enormous volumes of wastewater, which is increasingly utilized as a valuable resource for irrigation in urban and peri-urban agriculture. It drives significant economic activity, supports countless livelihoods particularly those of poor farmers, and substantially changes the water quality of natural water bodies (Marshall et al., 2007). (12)

Sewage waste water irrigation leads to accumulation of heavy metals in the soil. Sewage waste has been implicated as a potential source of heavy metals such as Copper $(\mathrm{Cu})$, Cadmium (Cd), Zinc ( $\mathrm{Zn}$ ), Lead (Pb), Nickel (Ni) and Iron $(\mathrm{Fe})$ in the edible and non-edible parts of vegetables. Food safety issues and potential health risks make this as one of the most serious environment concern. There is evident to indicate that agriculture soil also has increased levels of heavy metals as a result of increased in anthropogenic activities. Waste water carries appreciable amount of trace toxic metals which often leads to degradation of soil, health and contamination of food chain mainly through the vegetable grown on such soils. The toxic elements accumulated in organic matter in soil are taken up by growing plants and lastly exposing humans to this contamination. (1).

Vegetables are major components of human diet, being sources of essential nutrients, antioxidants and metabolites in food items. In the present study the concentration of heavy metals in locally produced vegetables quantified in around Yamuna river Allahabad city of India.(3)

\section{Materials and Methods}

\section{Study Area}

The present work entitled was conducted in research laboratory of Warner School of Food and Dairy Technology, Department of soil science SHIATS, and Faculty of food analysis and research laboratory Center for Food Technology in Allahabad University, from September 2014 to April 2015. The sample of vegetables and soil was collected from waste water irrigated Yamuna banks where crops are irrigated with wastewater which is coming directly from the municipality. Our study area is situated in the left side of the Yamuna River around $10 \mathrm{~km}$ south of Allahabad city. The common vegetables grown in this area is cucumber, spinach, ladyfinger, ridge gourd and etc. which are supplied to the all vegetables market in Allahabad and the rest entire the common market. In this study we investigated the concentration of $\mathrm{Pb}, \mathrm{Ni}, \mathrm{Cd}$, and $\mathrm{Cu}$ in soil and vegetables grown in this agricultural land area having long term uses of the treated and untreated wastewater for irrigation.

\section{Soil and plant analysis:}

20 samples were selected from each site. Four selected vegetables samples were of cucumber, spinach, ladyfinger and ridge gourd. The samples were collected by hand using vinyl gloves carefully packed into polyethylene bags and the whole plant body was brought to the laboratory, During the month from September 2014 to April 2015 in clean, presterilized sampling bags in order to estimate the total heavy metal content $(\mathrm{Cu}, \mathrm{Cd}, \mathrm{Pb}$ and $\mathrm{Ni})$. First vegetable sample sliced and air dried in a piece of paper and subsequently oven-dried on a constant weight at $65{ }^{\circ} \mathrm{C}$ for 48 hours, ground with a ceramic-coated grinder (Liuetal. 2006) and 


\section{International Journal of Science and Research (IJSR) \\ ISSN (Online): 2319-7064 \\ Index Copernicus Value (2013): 6.14 | Impact Factor (2014): 5.611}

stored in a dry place for further analysis of heavy metals. Plant and soil samples were digested in $15 \mathrm{ml}$ of $\mathrm{HNO}_{3}$, $\mathrm{H}_{2} \mathrm{SO}_{4}$ and $\mathrm{HClO}_{4}$ mixture $(5: 1: 1)$ at $80{ }^{\circ} \mathrm{C}$ until a transparent solution will obtained (Allen et al.1986). These transparent solutions were then filtered through Whatman filter paper number 42 and diluted to $50 \mathrm{ml}$ with distilled water. The concentrations of heavy metals in the filtrate were determined by using Atomic Absorption Spectrophotometer (Per Kin Elmer Analyst 400).

\section{Results and Discussion}

Vegetables samples of spinach (Beta vulgaris L), Cucumber (Cucumis sativus), ladyfinger (Abelmoschus esculentus Moench) and Ridge gourd (Cucurbitaceae), were collected from Mahewa path and Arail Ghat sites around yamuna river of Allahabad city, to study the heavy metal $(\mathrm{Cu}, \mathrm{Cd}, \mathrm{Pb}, \mathrm{Ni})$ concentration. Leafy vegetables were preferred for sampling since past research indicates that they accumulate heavy metals at a greater capacity than other vegetables (Jinadasa et al., 1997). The study showed that the concentration of $\mathrm{Pb}$ varied greatly in all vegetables (Table $1,2)$. Spinach got the higher average mean concentration of $\mathrm{Pb}(18.764 \mathrm{mg} / \mathrm{L})$, followed by ladyfinger $(15.227 \mathrm{mg} / \mathrm{L})$, Ridge gourd $(5.117 \mathrm{mg} / \mathrm{L})$ and cucumber $(2.602 \mathrm{mg} / \mathrm{L})$ and $\mathrm{Cu}(1.372 \mathrm{mg} / \mathrm{L})$ was higher in spinach followed by cucumber $(0.369 \mathrm{mg} / \mathrm{L})$, ladyfinger $(0.182 \mathrm{mg} / \mathrm{L})$ and Ridge gourd $(0.170 \mathrm{mg} / \mathrm{L})$, in site one (Mahewa path). The average mean concentration of $\mathrm{Pb}$ in spinach, cucumber, ladyfinger and Ridge gourd were $(4.333 \mathrm{mg} / \mathrm{L}),(5.079$ $\mathrm{mg} / \mathrm{L}),(10.407 \mathrm{mg} / \mathrm{L})$ and $(10.779 \mathrm{mg} / \mathrm{L})$ respectively, in case of $\mathrm{Cu}$ Ridge gourd $(0.269 \mathrm{mg} / \mathrm{L})$ got the highest amount followed by spinach $(0.237 \mathrm{mg} / \mathrm{L})$, cucumber $(0.227 \mathrm{mg} / \mathrm{L})$ and ladyfinger $(0.218 \mathrm{mg} / \mathrm{L})$ in site two (Arail Ghat) .

Heavy metal concentration showed variation among different vegetables collected from both sites, four elements examined in four vegetables irrigated with waste water in two selected sites of Allahabad areas. The average concentration of heavy metals $\mathrm{Cu}, \mathrm{Cd}, \mathrm{Pb}$ and $\mathrm{Ni}$ were $(1.372 \mathrm{mg} / \mathrm{L}),(0.017 \mathrm{mg} / \mathrm{L}),(18.764 \mathrm{mg} / \mathrm{L})$ and $(0.030$ $\mathrm{mg} / \mathrm{L})$ respectively in spinach from site one. Meanwhile the concentration of $\mathrm{Cu}, \mathrm{Cd}, \mathrm{Pb}$ and $\mathrm{Ni}$ in cucumber were $(0.369$ $\mathrm{mg} / \mathrm{L}),(0.007 \mathrm{mg} / \mathrm{L}),(2.602 \mathrm{mg} / \mathrm{L})$ and $(0.020 \mathrm{mg} / \mathrm{L})$ respectively from site one (Mahewa Path). Whereas in ladyfinger the average concentration of heavy metals $\mathrm{Cu}$, $\mathrm{Cd}, \mathrm{Pb}$ and $\mathrm{Ni}$ were $(0.182 \mathrm{mg} / \mathrm{L}),(0.008 \mathrm{mg} / \mathrm{L}),(15.227$ $\mathrm{mg} / \mathrm{L})$ and $(0.015 \mathrm{mg} / \mathrm{L})$ respectively in site one (Mahewa Path). Last vegetable in site one (Mahewa path) was Ridge gourd which was having $(0.170 \mathrm{mg} / \mathrm{L}),(0.005 \mathrm{mg} / \mathrm{L}),(5.117$ $\mathrm{mg} / \mathrm{L})$ and $(0.015 \mathrm{mg} / \mathrm{L})$ respectively for the elements $\mathrm{Cu}$, $\mathrm{Cd}, \mathrm{Pb}$ and. In comparison with the standard guideline for vegetables (WHO, 2007) it was found that mean value of $\mathrm{Pb}$ concentration in vegetables exceeded the recommended level. In comparison with site two (Arail Ghat) the mean concentration of $\mathrm{Pb}(10.428 \mathrm{mg} / \mathrm{L})$ and $\mathrm{Cu}(0.523 \mathrm{mg} / \mathrm{L})$ were high in all vegetables, whereas the mean concentration of $\mathrm{Cd}(0.009 \mathrm{mg} / \mathrm{L})$ and $\mathrm{Ni}(0.020 \mathrm{mg} / \mathrm{L})$ were almost in same quantity. In individual comparison spinach has the highest mean concentration of $\mathrm{Pb}$ and $\mathrm{Cu}$ followed by lady finger in site one itself.
The average value of $\mathrm{Cu}$ was highest $(1.372 \mathrm{mg} / \mathrm{L})$ in spinach followed by in cucumber $(0.369)$ and the minimum was recorded in ridge guard. The order of average values of $\mathrm{Cu}$ was obtained as spinach $(1.372 \mathrm{mg} / \mathrm{L})>$ cucumber $(0.369 \mathrm{mg} / \mathrm{L})>$ ladyfinger $(0.182 \mathrm{mg} / \mathrm{L})>$ Ridge gourd $(0.170 \mathrm{mg} / \mathrm{L})$. Similarly, the average value of $\mathrm{Cd}$ was highest $(0.017 \mathrm{mg} / \mathrm{L})$ in spinach followed by in lady finger $(0.008 \mathrm{mg} / \mathrm{L})$ and the minimum was recorded in Ridge gourd $(0.005 \mathrm{mg} / \mathrm{L})$. The order of average values of $\mathrm{Cd}$ was obtained as spinach $(0.017 \mathrm{mg} / \mathrm{L})>$ ladyfinger $(0.008 \mathrm{mg} / \mathrm{L})$ $>$ cucumber $(0.182 \mathrm{mg} / \mathrm{L})>$ Ridge gourd $(0.170 \mathrm{mg} / \mathrm{L})$. Moreover, the average value of $\mathrm{Pb}$ was highest (18.764) in spinach followed by in ladyfinger $(15.227 \mathrm{mg} / \mathrm{L})$ and Ridge gourd $(5.117 \mathrm{mg} / \mathrm{L})$ and the minimum was recorded in cucumber $(2.602 \mathrm{mg} / \mathrm{L})$. The order of average values of $\mathrm{Cu}$ was obtained as spinach $(18.764 \mathrm{mg} / \mathrm{L})>$ ladyfinger $(15.227$ $\mathrm{mg} / \mathrm{L})>$ Ridge gourd $(5.117 \mathrm{mg} / \mathrm{L})>$ cucumber $(2.602$ $\mathrm{mg} / \mathrm{L})$. In case of nickel the average value of $\mathrm{Ni}$ was highest $(0.030 \mathrm{mg} / \mathrm{L})$ in spinach followed by in cucumber $(0.020$ $\mathrm{mg} / \mathrm{L})$ and the minimum was recorded in ridge guard. The order of average values of $\mathrm{Ni}$ was obtained as spinach $(0.030$ $\mathrm{mg} / \mathrm{L})>$ cucumber $(0.020 \mathrm{mg} / \mathrm{L})>$ ladyfinger $(0.015 \mathrm{mg} / \mathrm{L})$ $>$ Ridge gourd $(0.015 \mathrm{mg} / \mathrm{L})$.

The average mean concentration of heavy metals $(\mathrm{mg} / \mathrm{kg}$ dry weight) were 0.237 for $\mathrm{Cu}, 0.014$ for $\mathrm{Cd}, 4.333$ for $\mathrm{Pb}$ and 0.019 for $\mathrm{Ni}$ in spinach from site two, whereas average mean concentration of $\mathrm{Cu}, \mathrm{Cd}, \mathrm{Pb}$ and $\mathrm{Ni}$ in cucumber were $0.227,0.006,5.079$ and 0.020 respectively, heavy metal concentration $(\mathrm{Cu}, \mathrm{Cd}, \mathrm{Pb}$ and $\mathrm{Ni})$ in lady finger were 0.218 , $0.010,10.407$ and 0.016 respectively, Meanwhile the mean concentration of heavy metals like $\mathrm{Cu}, \mathrm{Cd}, \mathrm{Pb}$ and $\mathrm{Ni}$ in Ridge gourd were $0.269,0.005,10.779$ and 0.023 respectively. Here also the average mean concentration of $\mathrm{Pb}$ were the highest among all vegetables following by $\mathrm{Cu}$. Individually Ridge gourd was having the highest level of $\mathrm{Pb}$ followed by ladyfinger, cucumber and spinach. In comparison with site one the mean concentration of all elements were less, but In comparison with the standard guideline for vegetables ( WHO, 2007) it was found that mean value of $\mathrm{Pb}$ concentration in all vegetables exceeded the recommended level. Heavy metal concentration showed variation among different vegetables collected from site one and two (fig.1,2).

The average value of $\mathrm{Cu}$ was highest $(0.269)$ in Ridge gourd followed by in spinach $(0.237)$ and the minimum was recorded in ladyfinger $(0.218)$. The order of average values of $\mathrm{Cu}$ was obtained as (0.269) Ridge gourd $>$ spinach $(0.237)>$ cucumber $(0.227)>$ ladyfinger $(0.218)$. Similarly, The average value of $\mathrm{Cd}$ was highest $(0.014)$ in spinach followed by in lady finger (0.010) and cucumber (0.006) and the minimum was recorded in Ridge gourd (0.005). The order of average values of $\mathrm{Cd}$ was obtained as spinach $(0.014)>$ ladyfinger $(0.010)>$ cucumber $(0.006)>$ Ridge gourd (0.005). Moreover, the average value of $\mathrm{Pb}$ was highest (10.779) in Ridge gourd followed by in ladyfinger (10.407) and ridge cucumber (5.079) and the minimum was recorded in spinach (4.333). The order of average values of $\mathrm{Cu}$ was obtained as ridge gourd (10.779) > ladyfinger $(10.407)>$ cucumber $(5.079)>\operatorname{spinach}(4.333)$. In case of nickel the average value of $\mathrm{Ni}$ was highest $(0.023)$ in Ridge gourd followed by in cucumber (0.020) and spinach (0.019) 


\section{International Journal of Science and Research (IJSR) \\ ISSN (Online): 2319-7064 \\ Index Copernicus Value (2013): 6.14 | Impact Factor (2014): 5.611}

the minimum was recorded in lady finger $(0.016)$. The order of average values of $\mathrm{Ni}$ was obtained as Ridge gourd (0.023) $>$ cucumber $(0.020)>$ spinach $(0.019)>$ ladyfinger $(0.016)$. Results of one way ANOVA shows that variation in the heavy metal concentration was significant due to treatment in $\mathrm{Cd}$ and the remaining all elements were non-significant. The variation in heavy metal concentration in vegetables of same site may be described to the differences in their morphology and physiology for heavy metal uptake, exclusion, accumulation and retention (carlton-smith and Davis, 1983; Kumar et al., 2009). Several fold higher concentration of $\mathrm{Pb}$ was observed in all vegetables in both sites. Among all vegetables in site one spinach had the highest level of $\mathrm{Pb}$ (18.764) followed by $\mathrm{Cu}$ (1.372). For other vegetables ladyfinger had highest level of $\mathrm{Pb}$ (15.27) in site one and Ridge gourd (10.779) in site two.

The maximum concentration of $\mathrm{Pb}$ was exhibited by spinach (18.764) in site one and Ridge gourd (10.779) in site two followed by ladyfinger in site one (15.27) and ladyfinger in site two (10.44) which exceeded the acceptable tolerance level of $\mathrm{WHO}$ for $\mathrm{Pb}$ by three and three times, respectively. $\mathrm{Pb}$ concentration in edible portions of all the vegetables examined in the present study were above the permissible levels recommended by WHO, India (Awashthi 2000) The mean $\mathrm{Pb}$ content in vegetables (9.0385) was lower than the values reported in Titagarh, west Bengal, (21.9-57.63 $\mathrm{mg} / \mathrm{kg})($ Gupta et al.2008) but comparatively higher than the $\mathrm{Pb}$ level reported in China $(0.18-7.75 \mathrm{mg} / \mathrm{kg}$ ) (liu et al.2006), (1.97-381 mg/kg) (Liu et al.2005) and in varnsi, India (3.09-15.74 mg/kg) (Sharma et al.2007). However it was significantly lower than the mean concentration of $\mathrm{Pb}$ $(409 \mathrm{mg} / \mathrm{kg}$ ) reported in vegetables from Turkey by Turkdogan et al.(2002). The higher concentration of $\mathrm{Pb}$ in all vegetables in both sites may be the result of fuel combustion from the rapid increase in traffic and city waste (Maleki and Zarasvand, 2008). (Nabulo et al. 2006) reported atmospheric deposition to be the dominant pathway for $\mathrm{Pb}$ to leafy vegetables.

Table 1: Heavy metals concentration $(\mathrm{mg} / \mathrm{L})$ in selected vegetables irrigated with untreated sewage water in Mahewa Path.

\begin{tabular}{|c|c|c|c|c|}
\hline Treatments & $\mathbf{u C}$ & $\mathbf{d C}$ & $\mathbf{b P}$ & $\mathbf{i N}$ \\
\hline Spinach & 1.372 & 0.017 & 18.764 & 0.030 \\
\hline Cucumber & 0.369 & 0.007 & 2.602 & 0.020 \\
\hline Ladyfinger & 0.182 & 0.008 & 15.227 & 0.015 \\
\hline Ridge guard & 0.170 & 0.005 & 5.117 & 0.015 \\
\hline Mean & $\mathbf{0 . 5 2 3}$ & $\mathbf{0 . 0 0 9}$ & $\mathbf{1 0 . 4 2 8}$ & $\mathbf{0 . 0 2 0}$ \\
\hline F- test & $\mathrm{NS}$ & $\mathrm{S}$ & $\mathrm{NS}$ & $\mathrm{NS}$ \\
\hline S. Ed. $( \pm)$ & 0.455 & 0.002 & 10.155 & 0.006 \\
\hline C. D. $(\mathbf{P}=\mathbf{0 . 0 5})$ & & 0.004 & & \\
\hline
\end{tabular}

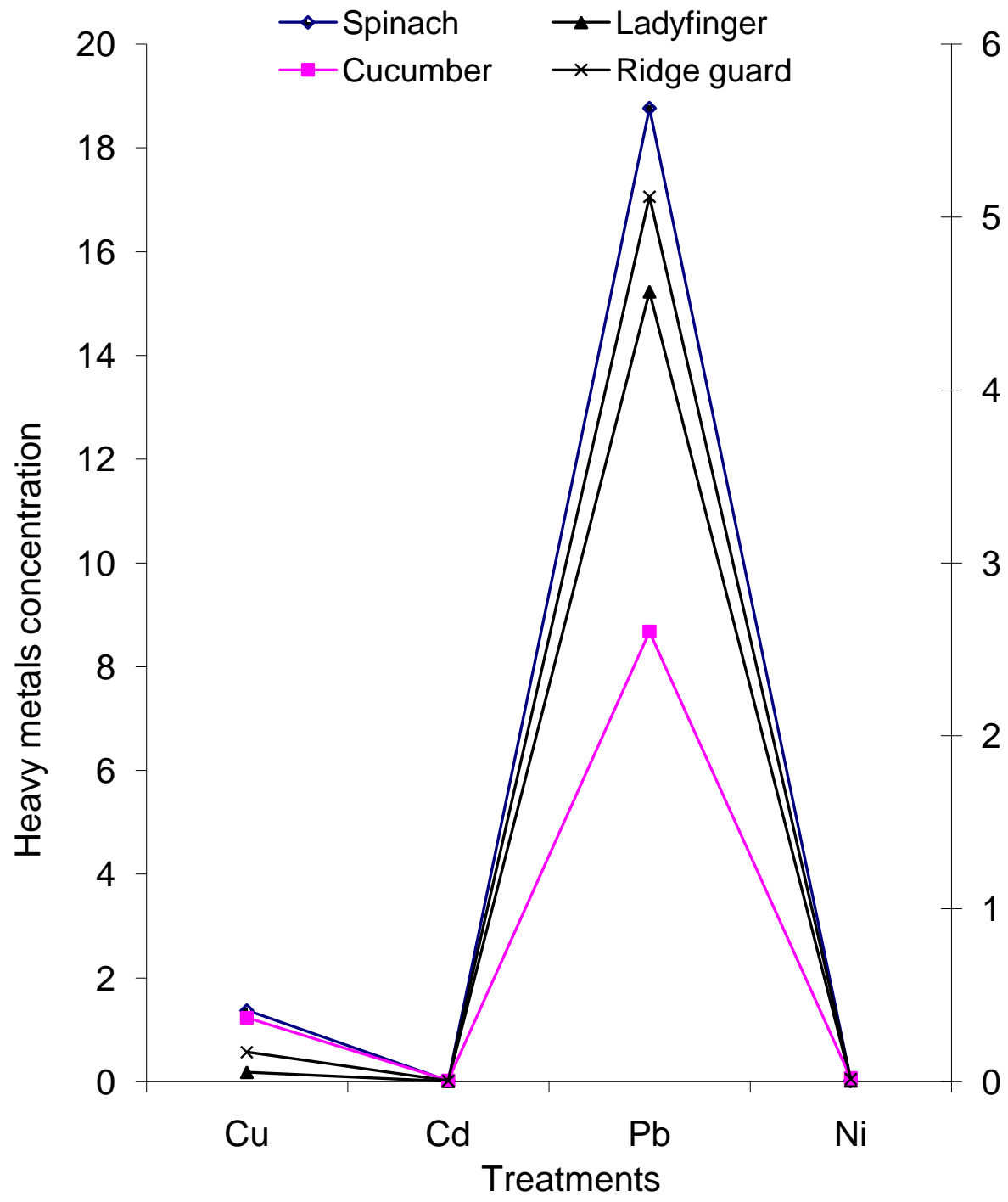




\section{International Journal of Science and Research (IJSR) \\ ISSN (Online): 2319-7064}

Index Copernicus Value (2013): 6.14 | Impact Factor (2014): 5.611

Table 2: Heavy metals concentration $(\mathrm{mg} / \mathrm{L})$ in selected vegetables irrigated with untreated sewage waste water in Arail Ghat.

\begin{tabular}{|c|c|c|c|c|}
\hline Treatments & $\mathbf{u C}$ & $\mathbf{d C}$ & $\mathbf{b P}$ & $\mathbf{i N}$ \\
\hline Spinach & 0.237 & 0.014 & 4.333 & 0.019 \\
\hline Cucumber & 0.227 & 0.006 & 5.079 & 0.020 \\
\hline Ladyfinger & 0.218 & 0.010 & 10.407 & 0.016 \\
\hline Ridge guard & 0.269 & 0.005 & 10.779 & 0.023 \\
\hline Mean & $\mathbf{0 . 2 3 8}$ & $\mathbf{0 . 0 0 9}$ & $\mathbf{7 . 6 4 9}$ & $\mathbf{0 . 0 1 9}$ \\
\hline F- test & $\mathrm{NS}$ & $\mathrm{S}$ & $\mathrm{NS}$ & $\mathrm{NS}$ \\
\hline S. Ed. ( $\mathbf{(})$ & 0.108 & 0.001 & 7.538 & 0.005 \\
\hline C. D. $(\mathbf{P}=\mathbf{0 . 0 5})$ & & 0.002 & & \\
\hline
\end{tabular}

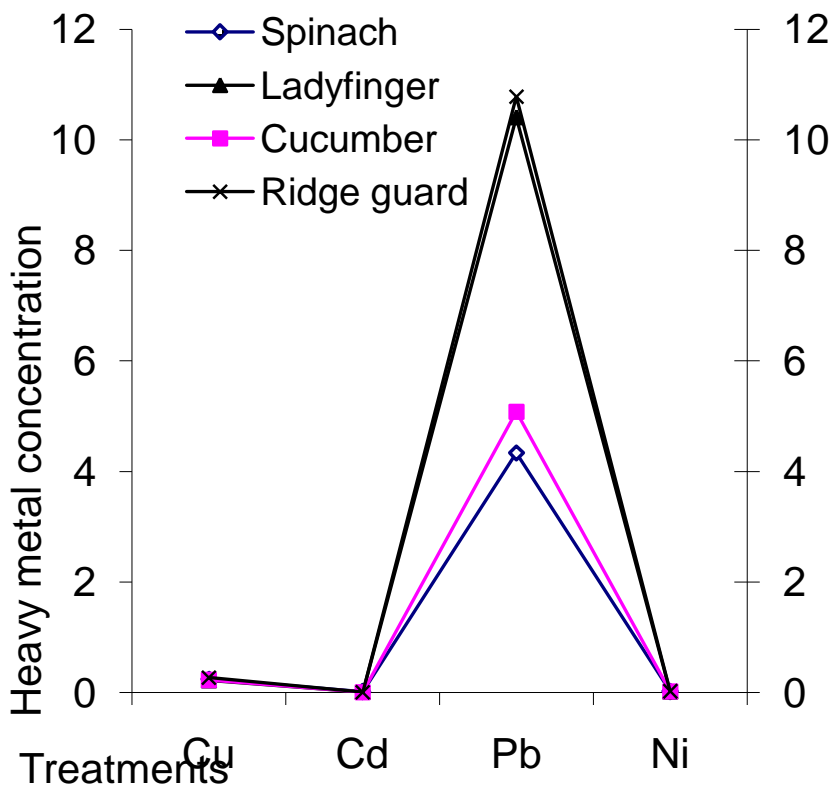

\section{Conclusion}

The long term waste water irrigation led to the accumulation of heavy metals in soil and consequently into the vegetables. Heavy metal concentration varied among the test vegetables, which reflect the differences in their uptak capabilities and their further translocation to edible portion of the plants. $\mathrm{Pb}$ and $\mathrm{Cu}$ were above the national and international permissible limits in all the vegetables. Target hazard quation of heavy metals also suggests that $\mathrm{Pb}$ and $\mathrm{Cu}$ concentration in most of the test vegetables had potential for human health risk due to consumption of plants grown in the area having long term uses of untreated waste water for irrigation. Long term consumption of these metalcontaminated vegetables can cause different disease like Brain and Kidney damage, cancer in human body, dermatitis. Responsible agencies should carry out public health education within the consumption area to sensitive the general public on the potential effects of indiscriminate disposal of waste and the potential health hazards associated with the consumption of vegetables cultivated with wastewater.

\section{References}

[1] Agrawal, R., Sharma, R.K., Singh, R.P., 2007. Contaminated Irrigation Water and Food Safety for the
Urban and Peri-urban Poor: Appropriate Measures for Monitoring and Control from Field Research in India and Zambia, Incpetion Report DFID Enkar R8160, SPRU, University of Sussex. $<$ www.pollutionandfood.net $>$.

[2] Allen, S.E., Grimshaw, H.M., Rowland, A.P., 1986. Chemical analysis. In: Moore, P.D.,and vegetables in suburban areas of Varanasi, India. Ecotoxicol. Environ. Saf. 66, 258-266.

[3] Awashthi, S. K. (2000). Prevention of Food Adulteration Act No. 37 of 1954. Central and State rules as amended for 1999 (3rd ed.). New Delhi: Ashoka Law House.

[4] Carlton-Smith, C.H., Davis, R.D., 1983. Comparative uptake of heavy metals by forage crops grown on sludge-treated soils. In: Proceeding of International Conference on Heavy metals in the Environment. CEP Consultants Ltd., Edinburg, UK, pp. 3933-3940.

[5] Chapman, S.B. (Eds.), Methods in Plant Ecology. Blackwell, Scientific Publication, Oxford, London, pp. 285-344.

[6] contamination of vegetable foodstuffs in Jaipur (India). Electron. J. Environ. Agri. Food Chem. 8 (2), 96-101

[7] Gupta, N., Khan, D. K., \& Santra, S. C. (2008). An assessment of heavy metal contamination in vegetables grown in wastewater-irrigated areas of Titagarh, West Bengal, India. Bulletin of Environmental Contamination and Toxicology, 80, 115-118. Doi: 10.1007/ s00128007-9327-z.

[8] Kumar, A., Sharma, I.K., Sharma, A., Varshney, S. Verma, P.S., 2009. Heavy metals

[9] Liu, W. H., Zhao, J. Z., Ouyang, Z. Y., Soderlund, L., \& Liu, G. H. (2005). Impacts of sewage irrigation on heavy metals distribution and contamination. Environment International, 31, 805-812. doi:10.1016/ j.envint.2005.05.042.

[10]Liu, W., Li, X., Li, H. H. Sr, \& Wang, Y. W. (2006). Heavy metal accumulation of edible vegetables cultivated in agricultural soil in the Suburb of Zhengzhou City, People's Republic of China. Bulletin of Environmental. Contamination and Toxicology, 76, 163-170. doi:10.1007/s00128-006-0981-3.

[11]Liu, W.X., Li, H.H., Li, S.R., Wang, Y.W., 2006. Heavy metal accumulation of edible Maleki, A. \& Zarasvand, M. A. (2008). Heavy metals in selected edible vegetables and estimation of their daily intake in Sanandaj. Southeast Asian Journal of Tropical Medicine and Public Health, 39 (2), 335- 340.

[12] Marshall, F.M., Holden, J., Ghose, C., Chisala, B., Kapungwe, E., Volk, J., Agrawal, M.,Nabulo, G., Oryem-Origa, H. \& Diamond, M. (2006). Assessment of lead, cadmium, and zinc contamination of roadside soils, surface films, and vegetables in Kampala City, Uganda. Environmental Research, 101, 42-52. doi:10.1016/j.envres.2005.12.016.

[13] Sharma, R.K., Agrawal, M., Marshall, F.M., 2007 Heavy metals contamination of soil T"urkdogan, M. K., Kilicel, F., Kara, K., Tuncer, I. \& Uygan, I. (2002). Heavy metals in soil, vegetables and fruits in the endemic upper gastrointestinal cancer region of Turkey. Environmental Toxicology and Pharmacology, 13, 175179. 


\section{International Journal of Science and Research (IJSR) \\ ISSN (Online): 2319-7064}

Index Copernicus Value (2013): 6.14 | Impact Factor (2014): 5.611

[14] Vegetable cultivated by People's Republic of China. Bull. Environ. Contamin. Toxicol. 76, 163-170.

[15] WHO. 2007. Joint FAO/WHO Expert standards program codex Alimentation Commission. Geneva, Switzerland. Available online http://www.who.int [Accessed 10/09/2012]. 